\title{
Phosphite Integrated in Late Blight Treatment Strategies in Starch Potato Does Not Cause Residues in the Starch Product
}

\author{
Erland Liljeroth, ${ }^{\dagger}$ Åsa Lankinen, Erik Andreasson, and Erik Alexandersson \\ Department of Plant Protection Biology, Swedish University of Agricultural Sciences, Alnarp, SE-230 53, Sweden
}

\begin{abstract}
Currently available fungicides against potato late blight are effective but there are concerns about the sustainability of frequent applications and the risks of fungicide resistance. Therefore, we investigated how potassium phosphite can be integrated into late blight control programs with reduced fungicides in field trials. Phosphite was somewhat less effective than the conventional fungicides at suppressing late blight in the foliage, and the tubers contained less starch. However, when we reduced the amount of phosphite and combined it with reduced amounts of conventional fungicides, we observed no differ-

associated with the amount of phosphite applied to the foliage. Our analyses indicate that phosphite could replace some fungicides without exceeding the current European Union standards for the maximum residue levels in potato tubers. No phosphite was detected in the starch from the tubers. In 1 of 2 years, early blight (caused by Alternaria solani) was less severe in the phosphite treatments than in the treatments without phosphite. The integration of phosphite into current treatment strategies would reduce the dependence on conventional fungicides.
\end{abstract} ences in disease suppression, total yields, and tuber starch contents compared with the full treatments with conventional fungicides. The amount of phosphite detected in the harvested tubers was linearly
Keywords: early blight, late blight, maximum residue level, Phytophthora infestans, potassium phosphite, residues, starch potato
Late blight, caused by Phytophthora infestans, is a worldwide problem for potato growers. Currently available fungicides are effective but the sustainability of frequent fungicide applications during potato production is questionable. Numerous treatments are costly, and there are concerns over the environmental impacts and public acceptance (Haverkort et al. 2016). Moreover, the future availability of traditional fungicides may be limited. Improved cultivar resistance to the late blight pathogen and alternative control techniques that are not dependent on fungicidal chemicals is of great importance to future integrated pest management solutions.

Several recent studies have reported good potassium phosphite efficacy against late blight and tuber blight caused by $P$. infestans (Andreu et al. 2006; Cooke and Little 2002; Deliopoulos et al. 2010; Kromann et al. 2012; Liljeroth et al. 2016; Lobato et al. 2008, 2011; Mayton et al. 2008; Mulugeta et al. 2019a). Phosphite has dual effects; it directly acts on the pathogen and indirectly enhances the plant's defense (Burra et al. 2014; Gao et al. 2018; Lim et al. 2013; Machinandiarena et al. 2012). Phosphite also has effects against other pathogens (Trejo-Téllez and Gómez-Merino 2018), and we recently found that its foliar application deters potato tuber moth in field-grown potato (Mulugeta et al. 2019b). Further evidence for the indirect resistance-inducing effects of phosphite was recently presented in a study of the potato leaf metabolome, in which Wu et al. (2019) observed higher levels of compounds produced in the phenylpropanoid pathway after phosphite treatment. The effect of plant resistance inducers (PRIs) on disease occurrence in Solanaceous crops was reviewed by Alexandersson et al. (2016) and there are several examples of significant disease control under field conditions. PRIs are commonly less effective at disease control than traditional

${ }^{\dagger}$ Corresponding author: E. Liljeroth; Erland.Liljeroth@slu.se

Funding: We thank the Swedish Farmer's Foundation for Agricultural Research and "Partnerskap Alnarp", SLU, Sweden, for financial support.

The author(s) declare no conflict of interest.

Accepted for publication 20 April 2020.

(C) 2020 The American Phytopathological Society fungicides but their integration into novel disease management strategies with fungicides may add another mode of action against pathogens (Sandroni et al. 2020). This may reduce fungicide use and the selective pressure for fungicide resistance, while still achieving efficient disease control.

Plant protection products based on potassium phosphite are registered and used on potato crops in North America but not in Europe. These products are used on other European crops but they are not currently approved for potato. The toxicity of phosphite is very low but some issues of the possible health or environmental side effects remain unclear (EFSA 2012). Phosphite is taken up by plants but cannot be metabolized and, thus, be used as a phosphorous source (Cohen and Coffey 1986; Thao and Yamakawa 2009). Instead, phosphite is transported to different organs, including the tubers, resulting in phosphite residues in the harvested product (Huang et al. 2018). The European Union (EU) presently considers the maximum residue levels (MRLs) of fosetyl-Al $\left(30 \mathrm{mg} \mathrm{kg}^{-1}\right.$ in potato and 100 $\mathrm{mg} \mathrm{kg}^{-1}$ in tomato) (EFSA 2014) as an applicable guideline for phosphite. Liljeroth et al. (2016) applied phosphite as Proalexin (LMI, Helsingborg, Sweden) 12 times per season and observed $\mathrm{PO}_{3}$ residue levels of 27 to $205 \mathrm{mg} \mathrm{kg}^{-1}$ (depending on the application amount) in the harvested tubers.

The current EU MRL standards for phosphite in potato suggest that it may be more realistic to use phosphite for starch potato production because the tubers are not directly consumed by humans. Phosphite is highly soluble in water; thus, it may be washed away in the starch extraction process when the starch is separated from the other fractions. Moreover, Liljeroth et al. (2016) observed better phosphite effects against late blight in more resistant cultivars, which is usually the case for starch potato.

This study aimed to investigate whether potassium phosphite can be integrated into current fungicide treatment strategies against late blight in starch potato. In field trials over two growth seasons, we studied the effects of potassium phosphite on late blight development in starch potato in isolation and when combined with reduced fungicide doses. We also analyzed the effects of phosphite on crop yield by compiling the results from this study with previously published data (Liljeroth et al. 2016). Phosphite has broad-spectrum effects against pathogens (Trejo-Téllez and Gómez-Merino 2018); therefore, we also measured the development of early blight caused by Alternaria solani. Finally, we analyzed the phosphite contents of the starch and 
other fractions (pulp, fruit juice, and protein fraction) of the harvested and processed tubers and calculated the fate of phosphite in the starch processing factory. This allowed us to determine the doses and frequencies of phosphite application without exceeding the MRL.

\section{Materials and Methods}

Field experiments. Field experiments were performed in 2015 and 2016. The trials were carried out by the Swedish Rural Economy and Agricultural Societies in Mosslunda, south of Kristianstad, Sweden $(55.982250,14.105759)$. Potato crops were planted on 20 May 2015 and 11 May 2016. The field was fertilized with nitrogen (N), phosphorus $(\mathrm{P})$, and potassium $(\mathrm{K})$ according to common practice for potato: 200,80 , and $215 \mathrm{~kg} / \mathrm{ha}$ for $\mathrm{N}, \mathrm{P}$, and $\mathrm{K}$, respectively. Half of the $\mathrm{N}$ fertilizer was applied before planting and the other half 25 days after emergence. Each experiment had a randomized block design with four blocks, and each plot had five 10-m-long rows, from which the middle three rows were harvested. Between blocks 1 and 2 and blocks 3 and 4, three rows of untreated plants were grown to serve as the infectors of natural infections. No P. infestans inoculations were carried out. Starch potato cultivars used in 2015 were cultivars Kuras and Sarion, and only Kuras was used in 2016. Various treatments against late blight were conducted weekly or every 14 days (Tables 1 and 2), and the treatments with late blight fungicides at different doses were compared with potassium phosphite alone or potassium phosphite + the fungicides. The first treatment was applied around 20 June (treatment 1, T1; 40 days after planting) and continued weekly or, for some treatments, biweekly until crop maturation (treatment 12, T12). The fungicides were applied with a tractor boom designed for the field trials with a water volume of 300 liters/ha and pressure equal to 2 bar. The following fungicides were used: Ranman Top, active ingredient (a.i.) cyazofamid; Revus, a.i. mandipropamid; and Infinito, a.i. fluopicolide + propamocarb. Phosphite was applied as Proalexin (LMI AB Sweden; a.i. potassium phosphite). The field was irrigated according to need.

Table 1. Results from the 2015 field trials with different doses of fungicides, phosphite, and a combination of reduced fungicide dose and phosphite in two starch potato cultivars ${ }^{\mathrm{w}}$

\begin{tabular}{|c|c|c|c|c|}
\hline Treatment $^{\mathrm{x}}$ & Late blight (rAUDPC)y & Defoliation (rAUC) ${ }^{\mathrm{z}}$ & Early blight infection (\%) & Yield (ton/ha) \\
\hline \multicolumn{5}{|l|}{ Kuras } \\
\hline Untreated control & $0.105 \mathrm{a}$ & $0.339 \mathrm{a}$ & n.d. & $46.7 \mathrm{~b}$ \\
\hline Fungicide $100 \%$ dose & $0.003 \mathrm{~d}$ & $0.058 \mathrm{de}$ & $4.0 \mathrm{a}$ & $59.2 \mathrm{a}$ \\
\hline Fungicide $50 \%$ dose & $0.011 \mathrm{~cd}$ & $0.074 \mathrm{~d}$ & $2.8 \mathrm{ab}$ & $59.9 \mathrm{a}$ \\
\hline Fungicide $25 \%$ dose & $0.024 \mathrm{~b}$ & $0.115 \mathrm{c}$ & $3.1 \mathrm{ab}$ & $57.6 \mathrm{a}$ \\
\hline Fungicide $25 \%$ dose + phosphite $50 \%$ dose & $0.006 \mathrm{~d}$ & $0.067 \mathrm{de}$ & $2.8 \mathrm{ab}$ & $58.3 \mathrm{a}$ \\
\hline Phosphite $100 \%$ dose & $0.001 \mathrm{~d}$ & $0.051 \mathrm{e}$ & $2.7 \mathrm{abc}$ & $59.2 \mathrm{a}$ \\
\hline \multicolumn{5}{|l|}{ Sarion } \\
\hline Untreated control & $0.024 \mathrm{bc}$ & $0.213 \mathrm{~b}$ & n.d. & $36.4 \mathrm{c}$ \\
\hline Fungicide $100 \%$ dose & $0.000 \mathrm{~d}$ & $0.059 \mathrm{de}$ & $2.3 \mathrm{abcd}$ & $42.0 \mathrm{bc}$ \\
\hline Fungicide $50 \%$ dose & $0.001 \mathrm{~d}$ & $0.062 \mathrm{de}$ & $1.6 \mathrm{bcd}$ & $42.6 \mathrm{~b}$ \\
\hline Fungicide $25 \%$ dose & $0.001 \mathrm{~d}$ & $0.065 \mathrm{de}$ & $1.6 \mathrm{bcd}$ & $43.1 \mathrm{~b}$ \\
\hline Fungicide $25 \%$ dose + phosphite $50 \%$ dose & $0.002 \mathrm{~d}$ & $0.061 \mathrm{de}$ & $1.1 \mathrm{~cd}$ & $41.0 \mathrm{bc}$ \\
\hline Phosphite $100 \%$ dose & $0.000 \mathrm{~d}$ & $0.059 \mathrm{de}$ & $1.3 \mathrm{~cd}$ & $42.0 \mathrm{bc}$ \\
\hline
\end{tabular}

w Different letters indicate significant differences according to Tukey's test at $5 \%$ probability level; $n . d .=$ not determined because canopy was defoliated to $100 \%$.

${ }^{x}$ Fungicide treatments: Revus at T1, T3, T7, T8, and T9; Infinito at T4, T5, and T6; Ranman Top at T2, T10, T11, and T12; and 100\% dose: Revus (active ingredient [a.i.] mandipropamid) at 0.6 liters/ha, Infinito (a.i. fluopicolide + propamocarb) at 1.6 liters/ha, and Ranman Top (a.i. cyazofamid) at 0.5 liters/ ha. Phosphite treatments: Proalexin (a.i. potassium phosphite) at T1 to T12; 100\% dose: 5 liters/ha.

y Relative area under the disease progress curve (rAUDPC) until 3 September.

$\mathrm{z}$ Area under the defoliation curve (rAUC) until 24 September.

Table 2. Results from the 2016 field trials with different doses of fungicides, phosphite, and combinations of reduced fungicide doses and phosphite in the starch potato cultivar Kuras ${ }^{\vee}$

\begin{tabular}{|c|c|c|c|c|c|c|c|}
\hline $\begin{array}{l}\text { Treatment } \\
\text { (dose percentages) }^{\mathrm{w}}\end{array}$ & Weeks $^{\mathbf{x}}$ & $\begin{array}{l}\text { Late blight } \\
\text { (rAUDPC)y }\end{array}$ & $\begin{array}{c}\text { Defoliation } \\
(\text { rAUC })^{\mathrm{z}}\end{array}$ & $\begin{array}{c}\text { Early blight } \\
(\%)\end{array}$ & $\begin{array}{c}\text { Yield } \\
\text { (ton/ha) }\end{array}$ & $\begin{array}{c}\text { Starch content } \\
(\%)\end{array}$ & $\begin{array}{l}\text { Starch yield } \\
\text { (ton/ha) }\end{array}$ \\
\hline Untreated control & & $0.184 \mathrm{a}$ & $0.307 \mathrm{a}$ & n.d. & $47.2 \mathrm{c}$ & $21.0 \mathrm{a}$ & $9.9 \mathrm{~b}$ \\
\hline Fungicide $100 \%$ & 1 & $0.009 \mathrm{ef}$ & $0.070 \mathrm{~cd}$ & $20.3 \mathrm{a}$ & $58.1 \mathrm{ab}$ & $22.3 \mathrm{a}$ & $13.0 \mathrm{a}$ \\
\hline Fungicide $50 \%$ & 1 & 0.015 def & $0.071 \mathrm{~cd}$ & $17.4 \mathrm{a}$ & $57.2 \mathrm{ab}$ & $22.7 \mathrm{a}$ & $13.0 \mathrm{a}$ \\
\hline Fungicide $25 \%$ & 1 & $0.032 \mathrm{~cd}$ & $0.089 \mathrm{bcd}$ & $16.8 \mathrm{a}$ & $57.2 \mathrm{ab}$ & $22.8 \mathrm{a}$ & $13.1 \mathrm{a}$ \\
\hline Fungicide $50 \%+$ phosphite $50 \%$ & 1 & $0.005 \mathrm{f}$ & $0.056 \mathrm{~cd}$ & $15.1 \mathrm{a}$ & $59.2 \mathrm{a}$ & $21.8 \mathrm{a}$ & $12.9 \mathrm{a}$ \\
\hline Fungicide $25 \%+$ phosphite $75 \%$ & 1 & $0.004 \mathrm{f}$ & $0.048 \mathrm{~d}$ & $12.3 \mathrm{a}$ & $56.9 \mathrm{ab}$ & $22.1 \mathrm{a}$ & $12.5 \mathrm{a}$ \\
\hline Fungicide $25 \%+$ phosphite $50 \%$ & 1 & 0.007 ef & $0.070 \mathrm{~cd}$ & $16.4 \mathrm{a}$ & $58.1 \mathrm{ab}$ & $22.4 \mathrm{a}$ & $13.0 \mathrm{a}$ \\
\hline Phosphite $100 \%$ & 1 & 0.026 cde & $0.076 \mathrm{~cd}$ & $12.3 \mathrm{a}$ & $58.6 \mathrm{ab}$ & $21.4 \mathrm{a}$ & $12.5 \mathrm{a}$ \\
\hline Phosphite 50\% & 1 & $0.043 \mathrm{bc}$ & $0.106 \mathrm{bc}$ & $14.8 \mathrm{a}$ & $55.8 \mathrm{ab}$ & $21.3 \mathrm{a}$ & $11.9 \mathrm{a}$ \\
\hline Phosphite $25 \%$ & 1 & $0.060 \mathrm{~b}$ & $0.137 \mathrm{~b}$ & $11.8 \mathrm{a}$ & $52.7 \mathrm{bc}$ & $22.0 \mathrm{a}$ & $11.6 \mathrm{a}$ \\
\hline Fungicide $50 \%$ + phosphite $100 \%$ & 2 & 0.008 ef & $0.060 \mathrm{~cd}$ & $14.0 \mathrm{a}$ & $59.0 \mathrm{ab}$ & $21.5 \mathrm{a}$ & $12.7 \mathrm{a}$ \\
\hline Fungicide $100 \%$ + phosphite $100 \%$ & 2 & $0.006 \mathrm{f}$ & $0.056 \mathrm{~cd}$ & $12.3 \mathrm{a}$ & $60.6 \mathrm{a}$ & $21.3 \mathrm{a}$ & $12.9 \mathrm{a}$ \\
\hline
\end{tabular}

v Different letters indicate significant differences according to Tukey's test at $\% \%$ probability level; n.d. = not determined because canopy was defoliated to $100 \%$.

${ }^{w}$ Fungicide treatments at 1-week interval: Revus at T1, T3, T7, T8, and T9; Infinito at T4, T5, and T6; and Ranman Top at T2, T10, T11, and T12. Fungicide treatments at 2-week interval: Revus at T1, T3, T7, and T9; Infinito at T5; Ranman Top at T11; and 100\% dose: Revus (active ingredient [a.i.] mandipropamid) at 0.6 liters/ha, Infinito (a.i. fluopicolide + propamocarb) at 1.6 liters/ha, and Ranman Top (a.i. cyazofamid) at 0.5 liters/ha. Phosphite at 1-week interval: Proalexin at T1 to 12; phosphite at 2-week interval: Proalexin at T1, T3, T5, T7, T9, and T11; and 100\% dose: Proalexin (a.i. potassium phosphite) at 5 liters/ha.

$x$ Treatment interval.

y Relative area under the disease progress curve (rAUDPC).

z Area under the defoliation curve (rAUC). 
Disease assessment. The percentage of late blight infection was scored weekly, as described by Liljeroth et al. (2016). Early blight disease severity was determined two times at the end of the season as a percentage of the remaining green leaves with necrotic spots (Odilbekov et al. 2016).

Yield and tuber blight. Plants were harvested on 20 October 2015 and 14 October 2016. The staff at the Swedish Rural Economy and Agricultural Societies determined the yield per plot in several size fractions, and the total yield was calculated. Subsamples of $6 \mathrm{~kg} /$ plot were investigated for the presence of tuber blight and determined as a percentage of tubers with tuber blight symptoms (wt/wt).

The effects of potassium phosphite on yield were also investigated by compiling the data from this study with earlier published results (Liljeroth et al. 2016).

Starch content analysis. The starch content of the tubers was calculated from measurements of the specific weight, according to procedures detailed by the International Starch Institute, Denmark (http://www.starch.dk/isi/methods/13starch.htm). For this analysis, $5 \mathrm{~kg}$ of tubers were randomly sampled from each plot in 2016.

Phosphite residues in the tubers. Harvested tubers were analyzed for phosphite residues after approximately 5 months in storage at $5^{\circ} \mathrm{C}$ and $70 \%$ relative humidity. For each trial and treatment, $5 \mathrm{~kg}$ of tubers were stored and, in 2015, we analyzed the untreated control and treatment (Kuras) with full dose Proalexin (12 times). In 2016, we analyzed the untreated control and the treatments of $100 \%$ Proalexin (5 liters/ha), 50\% Proalexin, and 25\% Proalexin at 7-day intervals (12 times total), and the treatment with $100 \%$ Proalexin + fungicides every 14 days ( 6 times total). We analyzed the tuber samples from four replicate blocks of each trial and treatment.

Samples from other late blight trials with ware potato cultivars were also included in the analyses of phosphite contents, sampled by the Swedish Rural Economy and Agricultural Societies in 2013, 2014, and 2017, and in a trial with starch potato by Lyckeby Starch AB 2017 at the same experimental site. In these trials, phosphite was applied at different rates with fungicides in a randomized block design with the same plot size and four replications. In the 2013 ware potato trials, Sava was used, and phosphite was applied as Proalexin at 7.5 liters/ha 12 times, with a 7-day interval. In 2014, Bintje was used, and Proalexin was applied at 5 and 2.5 liters/ha 12 times, with a 7-day interval. In 2017, Belana was used, and phosphite was applied with a half dose of fungicides (i.e., 2.5 liters/ha Proalexin + $50 \%$ fungicide; Revus, Ranman Top, and Infinito, alternated) four times (treatment times 2, 4, 6, and 8). At treatments 1, 3, 5, 7, and 9 , only $100 \%$ fungicide was applied. The interval was 7 days. In 2017, a trial with starch potato Avenue was also conducted with phosphite as Proalexin at 2.5 liters/ha $+50 \%$ fungicides (Revus, Ranman Top, and Infinito, alternated) six times (treatment times T1, T3, T5, T9, and T11) at 14-day intervals. The trials were harvested by the staff of the Swedish Rural Economy and Agricultural Societies in mid-September (ware potato) and at the beginning of October (starch potato). The ware and starch potato tubers were stored for about 5 months before analysis.

Sections from six randomly chosen tubers (approximately $25 \mathrm{~g}$ each) were cut and pooled as finely chopped and carefully mixed pieces. Approximately $5 \mathrm{~g}$ fresh weight $(\mathrm{FW})$ of this mixture was extracted and ground in liquid nitrogen. Ground powder $(1 \mathrm{~g})$ was extracted according to Borza et al. (2014) in $10 \mathrm{mM}$ Tris- $\mathrm{HCl}, \mathrm{pH}$ 7.6 , at a ratio of $1: 10$. The slurry was centrifuged at $4,000 \times g$ for $10 \mathrm{~min}$, and the supernatant was transferred to new tubes and centrifuged again at $11,000 \times g$ for $15 \mathrm{~min}$ at room temperature. Macromolecules were removed by centrifugation at $4,000 \times g$ for 40 min using Amicon Ultra-4 centrifugal filter devices (Millipore Corp) with a molecular weight cutoff at 3,000 Da. The resulting filtrate was used for phosphite and phosphate analysis. AkzoNobel Pulp and Performance Chemicals (Bohus, Sweden) performed the ion chromatography analysis according to Borza et al. (2014).

Phosphite residues after tuber processing. Approximately $5 \mathrm{~kg}$ of tubers were randomly selected from the four replicate plots after harvest in 2015 and were processed into three fractions: starch, pulp, and fruit juice. This was performed on a laboratory scale but with the same methods as the commercial factory at Lyckeby Starch AB, Sweden. This is described by the International Starch Institute, Denmark (http://www.starch.dk/isi/profile/home.asp; http://www.starch.dk/isi/ starch/img/Tm05-5e\%20Potato\%20starch.pdf). From each fraction, $1 \mathrm{~g}$ (FW) was extracted and analyzed as described above. From the pulp and fruit juice, fiber and protein were isolated according to the commercial methods of Lyckeby Starch AB, Sweden. The fiber from the pulp was carefully washed with tap water, and the water was pressed out under pressure, followed by air drying. Proteins in the fruit juice were precipitated with acid (sulfuric acid) and heat. The precipitated proteins were separated, the water was removed; then, the proteins were air dried as described in a patent (WO1997003571A1/en). Fiber ( $1 \mathrm{~g}$ dry weight [DW]) and $0.2 \mathrm{~g}$ (DW) of protein were used for the extractions and analyses of phosphite described above.

Statistical analysis. The data were analyzed by calculating the area under the disease progress curve (AUDPC) (Shaner and Finney 1977). The relative AUDPC (rAUDPC) was calculated by dividing AUDPC by the total area during the assessment period. The area under the defoliation curve (rAUC) was also calculated.

The treatment effects were investigated via analysis of variance (ANOVA) using the SAS system (version 9.4; SAS, Cary, NC, U.S.A.). For multiple comparisons of the means, Tukey's test at a $5 \%$ probability level was used. In some cases, $\log \times$ transformations were performed to obtain a normal distribution.

\section{Results}

Field trial 2015: Effects of the treatment combinations on late and early blight in two cultivars. Late blight infections were first observed in the field on 23 July and progressed with a typical sigmoid (S-shaped) growth curve. On 3 September, the untreated control plots had an infection rate of approximately $51 \%$, while the infection rates of the treated plots were $2.1 \%$ (full dose fungicide), $6.7 \%$ (half dose fungicide), and $0.4 \%$ (Proalexin). The late blight severity measured as rAUDPC was much lower in the treated plots than in the untreated control (Table 1). There was a clear difference between the two cultivars; rAUDPC in all of the treatments was higher for Kuras than for the more resistant Sarion (ANOVA, $F=90, P<0.0001$ ). In Kuras, lower doses of the fungicides resulted in significantly higher infection rates compared with the higher doses. However, if the lowdose fungicides were combined with phosphite, the infection rate was comparable with the full fungicide doses (Table 1). Phosphite alone (full dose) resulted in the same level of late blight control as the recommended doses of fungicides in both cultivars. Late blight could only be accurately scored until the beginning of September; thereafter, it was not possible to distinguish late blight damage from senescence-related defoliation or other causes. Thus, from this point, total defoliation was scored. We observed similar results for rAUC (i.e., lower fungicide doses resulted in somewhat higher defoliation rates in Kuras but not in Sarion).

At the end of the season (i.e., mid-September), some early blight infections appeared in the field. At this point, the untreated plots were completely defoliated due to late blight but early blight infections were scored in the other plots on two occasions. On average, early blight infection was lower in Sarion than in Kuras (ANOVA, $F=$ 27.7, $P<0.0001)$

The yield was higher in the treated plots than in the untreated plots but the yield did not differ among the treatments. Kuras had a higher total yield than Sarion (ANOVA, $F=146, P<0.0001$ ), and Sarion is supposed to have a higher starch content than Kuras, suggesting similar starch yields.

Tuber blight occurred at low frequencies; only a few infected tubers were found, none of which affected the tuber yield.

Field trial 2016: Effects of the treatment combinations, doses, and intervals on late and early blight development. The first late blight infections were observed on 11 July and the untreated control had about $70 \%$ infection on 6 September. The effects of the different doses and intervals of fungicides and phosphite and the combinations were tested against late blight in Kuras. Similar to 2015, the reduced fungicide doses resulted in somewhat higher late blight severity (i.e., rAUDPC) (Table 2; Fig. 1). The phosphite effect was also dose 
dependent and, in contrast to 2015, phosphite was not as effective as the fungicides. However, phosphite combined with reduced fungicide doses did result in the same level of protection as the full doses of fungicides. On 6 September, we observed a $4.6 \%$ infection rate for the full fungicide dose, $6.7 \%$ for the half fungicide dose, $11.7 \%$ for the full phosphite dose, and $2.5 \%$ for the combined treatment. The 2-week interval with the combined treatment also resulted in similar levels of late blight control as the full fungicide doses at a 1-week interval. The rate of defoliation (rAUC) was even lower in the combined treatment than in the full-dose fungicide treatment.

The early blight infections were more severe in 2016 than in 2015 (scored on two occasions). As in 2015, the untreated control could not be scored on the first assessment date due to complete late blight-induced defoliation. There were no significant differences among the individual treatments. However, the phosphite-only treatments had significantly lower early blight infection rates than the treatments with only fungicides (ANOVA, $F=13.7, P=0.002$ ). On average, the infection rate was reduced by $30 \%$ compared with using only the late blight fungicides.

The total yields and starch yields of the treatments were significantly higher than the untreated control but there were no significant differences among the treatments (Table 2). The phosphite-only treatments had significantly lower starch yields than the fungicideonly treatments (ANOVA, $F=10.0, P=0.0064$ ), due to the higher starch contents in the fungicide-treated plots (ANOVA, $F=11.0, P=$ $0.0047)$. The total yields did not differ. Neither the total yields nor the starch yields of the combined treatments differed from the fungicideonly treatments.

Tuber blight occurred at low frequencies; only a few infected tubers were found, none of which affected the tuber yield.

Combined analysis of yield data from five field trials. The 2016 data with Kuras was combined with data from prior field experiments (2012 and 2013) using starch potato cultivars Seresta and Merano (Liljeroth et al. 2016). Similar treatments between experiments were analyzed and compared (Table 3 ). Phosphite alone resulted in somewhat higher infection rates of late blight compared with the fungicides. However, the combination of phosphite and reduced fungicides resulted in similar or improved protection compared with the fungicides alone (at full doses). The starch content tended to be lower in the phosphite-only treatments. The yield, starch content, and starch yield were further investigated with ANOVA to examine the effects of the treatment factors (fungicide or phosphite), dose ( 100 or $50 \%$ of the recommended dose), and experiment (five experiments during different years). Total yield did not differ between the fungicide- and phosphite-only treatments but the starch content $(F=$ $13.7, P=0.0006)$ and starch yield $(F=11.9, P=0.0012)$ were significantly lower in phosphite-only treatments. The dose did not have a significant effect, nor was there a significant interaction between treatment, dose, and experiment.

In the combined treatments (phosphite + fungicides), the starch yield was similar to the treatments with only fungicides.

Phosphite residues in the tubers and processed products. The phosphite contents of the harvested tubers were analyzed after approximately 5 months of storage at $4{ }^{\circ} \mathrm{C}$. In the treatment with the highest phosphite dose, the tubers contained $\mathrm{PO}_{3}$ at more than $100 \mathrm{mg} / \mathrm{kg} \mathrm{FW}$ of tuber in both years. The phosphite content decreased with lower doses (Table 4). We compiled the phosphite data from several trials and observed a linear relationship between the concentration of phosphite in the tubers and the total amount of phosphite applied to the field. This was true for the starch and ware potato (Fig. 2).

The phosphite contents of the starch, pulp, and fruit juice were also analyzed (Table 5). No phosphite was detected in the starch fraction of either cultivar. The pulp values ranged from $\mathrm{PO}_{3}$ at 15 to $71 \mathrm{mg} / \mathrm{kg}$ $\mathrm{FW}$, and the fruit juice values ranged from $\mathrm{PO}_{3}$ at 2.7 to $14 \mathrm{mg} / \mathrm{kg}$ FW, depending on the field application rates (Table 5).

The pulp and fruit juice were further processed into dried fiber (from pulp) and protein (from fruit juice), and the phosphite contents of both cultivars were analyzed again (Table 6). Phosphite was detected in the fiber only at a higher field application rate $\left(\mathrm{PO}_{3}\right.$ at 6.8 to $12.3 \mathrm{mg} / \mathrm{kg} \mathrm{DW}$ ), while higher values were observed in the protein fraction $\left(\mathrm{PO}_{3}\right.$ at 83.3 to $\left.100 \mathrm{mg} / \mathrm{kg} \mathrm{DW}\right)$.

Based on these analyses, calculations were made to unravel how the phosphite was distributed during starch processing (Table 7). Our calculations show that about $80 \%$ of the phosphite in the tubers ends up in the process water.
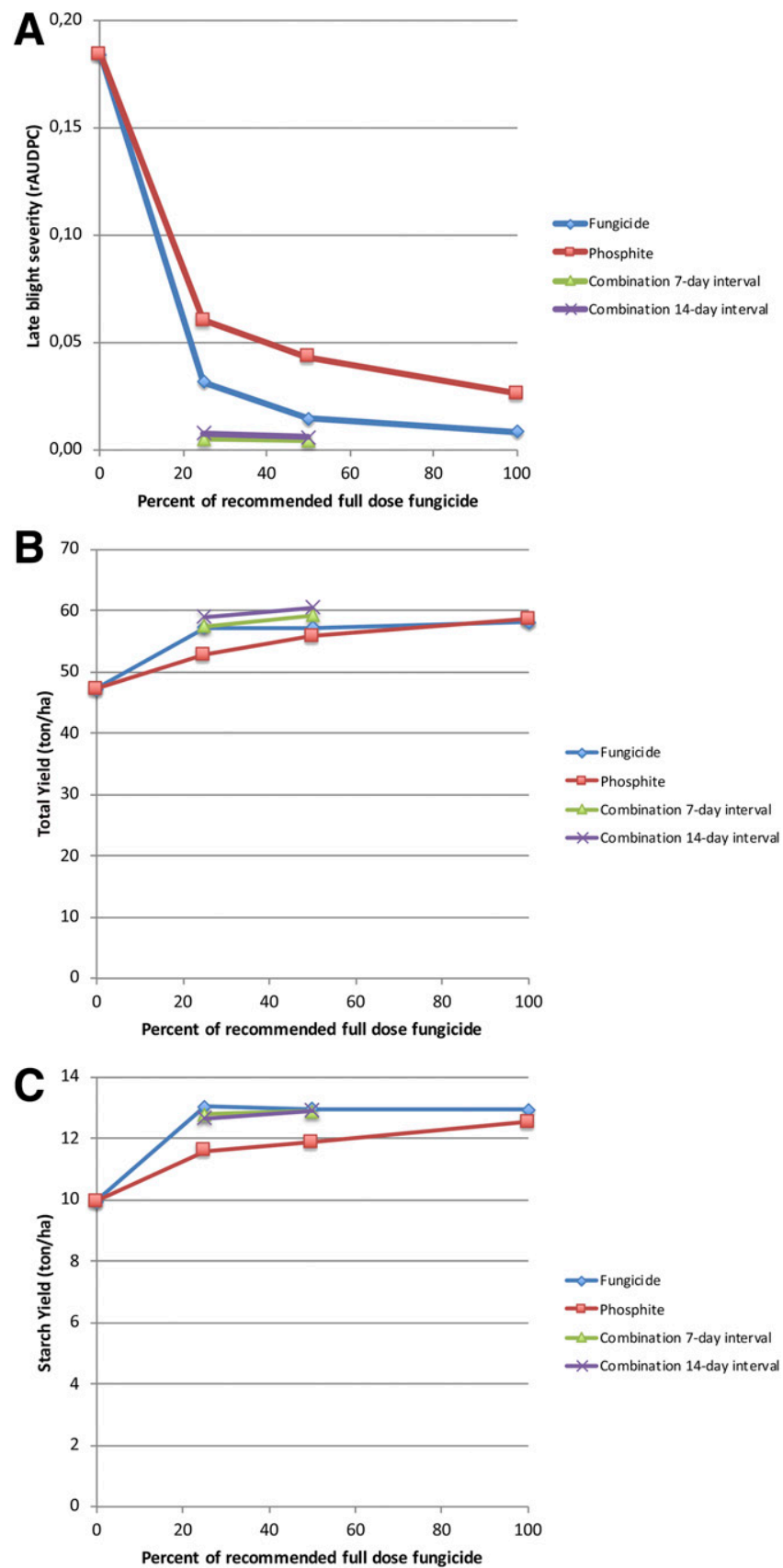

Fig. 1. Effects of different doses of fungicides and phosphite and the combinations of phosphite and fungicides in the 2016 field trial with Kuras on A, late blight infection; B, total yield; and $\mathbf{C}$, starch yield. In the fungicide treatment at 7-day intervals, the following fungicides were applied at 100, 50, and 25\% doses: Revus (active ingredient [a.i.] mandipropamid) at T1, T3, T7, T8, and T9; Infinito (a.i. fluopicolide + propamocarb) at T4, T5, and T6; and Ranman Top (a.i. cyazofamid) at T2, T10, T11, and T12. In the phosphite treatment, a 7-day interval with Proalexin (a.i. potassium phosphite) was applied at 100,50 , and $25 \%$ doses at T1 to T12. In the combined treatment, 7-day intervals with the same fungicides were applied at 50 and $25 \%$ doses and, at each treatment time (T1 to T12), they were combined (tank mixed) with a $50 \%$ dose of Proalexin. In the combined treatment with 14-day intervals, the following fungicides were applied at 100 and $50 \%$ doses: Revus at $\mathrm{T} 1, \mathrm{~T} 3, \mathrm{~T} 7$, and T9; Infinito at T5; and Ranman Top at T11. At each treatment time, the fungicides were combined (tank mixed) with $100 \%$ Proalexin. 


\section{Discussion}

The results of the field trials in this study confirm earlier reports on the efficacy of potassium phosphite against late blight in potato (Forrer et al. 2017; Kromann et al. 2012; Liljeroth et al. 2016; Lobato et al. 2008; Mulugeta et al. 2019a). In one trial, phosphite was nearly as effective as conventional fungicides but the fungicides provided somewhat better protection. However, the combined usage of halfdose fungicides and half-dose phosphite was as effective as fungicides alone (Fig. 1). A longer interval (14 days instead of 7 days) also resulted in good protection but this halved the total amount of fungicides applied. This is interesting because longer intervals would be economically feasible for growers. Reduced fungicide doses alone resulted in higher levels of infection.

The observation that phosphite also has a small effect against early blight in potato has never been reported. Fungicide resistance against several active substances used to combat early blight (e.g., azoxystrobin and boscalid) is an increasing problem (Edin et al. 2019; Landschoot et al. 2017; Odilbekov et al. 2016); thus, this result may contribute to future alternative control methods.

The total yield was similar among the different treatments. Thus, even with reduced doses and more infection when using phosphite alone, the yield was not significantly lower. However, phosphite alone (compared with the fungicide-only treatments) resulted in lower starch contents and lower starch yield. This may be due to the indirect mode of action of phosphite (i.e., inducing defensive responses in the plant) (Burra et al. 2014; Gao et al. 2018; Lim et al. 2013; Machinandiarena et al. 2012; Wu et al. 2019) that lead to costs associated with metabolic changes. A leaf proteomic study (Lim et al. 2013) indicated that enzymes involved in the glycogenic pathway and the citric acid cycle were downregulated by phosphite treatment, which may affect the levels of free sugars and starch accumulation. However, these possible physiological effects need to be studied in detail. Phosphite and half-dose fungicide treatments resulted in starch yields similar to those of the fungicide-only treatments, suggesting that the limited use of phosphite and fungicides could be used to control late blight without affecting yield, as illustrated in Figure 1.

Another important issue of using phosphite for plant protection programs is the residue levels in the harvested tubers. Phosphite is quickly taken up by the leaves and translocated to all parts of the plant (Cohen and Coffey 1986). Huang et al. (2018) reported

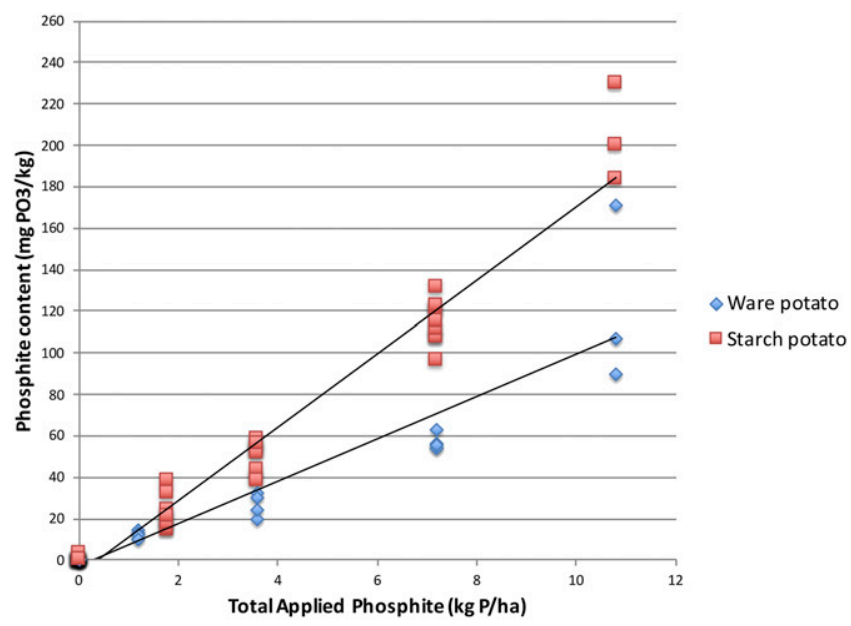

Fig. 2. Phosphite contents of the harvested tubers in relation to the amount of phosphite applied during the cropping season. Compiled data from several trials were $R^{2}=0.96$ for starch potato and $R^{2}=0.87$ for ware potato. Phosphite was applied in the field as Proalexin (active ingredient [a.i.] potassium phosphite) alone or combined with the fungicides Revus (a.i. mandipropamid), Infinito (a.i. fluopicolide + propamocarb), and Ranman Top (a.i. cyazofamid), as described in Materials and Methods.

Table 3. Combined analyses of the late blight infection rate, yield, starch content, and starch yield from five field trials ${ }^{\mathrm{x}}$

\begin{tabular}{lccccc}
\hline Treatmenty & Interval & Late blight (rAUDPC) $^{\mathbf{z}}$ & Yield (ton/ha) & Starch content (\%) & Starch yield (ton/ha) \\
\hline Untreated control & 7 days & $0.221 \mathrm{a}$ & $45.2 \mathrm{c}$ & $22.3 \mathrm{~b}$ & $10.0 \mathrm{~d}$ \\
Fungicide 100\% dose & 7 days & $0.090 \mathrm{~cd}$ & $49.8 \mathrm{ab}$ & $23.1 \mathrm{ab}$ & $11.5 \mathrm{abc}$ \\
Fungicide 50\% dose & 7 days & $0.093 \mathrm{~cd}$ & $49.6 \mathrm{ab}$ & $23.4 \mathrm{a}$ & $11.6 \mathrm{ab}$ \\
Phosphite 100\% dose & 7 days & $0.105 \mathrm{c}$ & $49.4 \mathrm{ab}$ & $22.4 \mathrm{~b}$ & $11.0 \mathrm{bc}$ \\
Phosphite 50\% dose & 7 days & $0.129 \mathrm{~b}$ & $47.8 \mathrm{bc}$ & $22.8 \mathrm{ab}$ & $10.8 \mathrm{c}$ \\
Combination fungicide 50\%/phosphite 50\% & 7 days & $0.085 \mathrm{~d}$ & $49.9 \mathrm{ab}$ & $22.8 \mathrm{ab}$ & $11.3 \mathrm{abc}$ \\
Combination fungicide 100\%/phosphite 100\% & 14 days & $0.084 \mathrm{~d}$ & $52.0 \mathrm{a}$ & $22.8 \mathrm{ab}$ & $11.8 \mathrm{a}$ \\
\hline
\end{tabular}

${ }^{x}$ Data from two field trials in 2012 and two trials in 2013 with the cultivars Seresta and Merano (Liljeroth et al. 2016) were combined with the 2016 Kuras data from this study. The fungicide-only treatments (in 2012 and 2013, Ranman Top was used and, in 2016, three fungicides were alternated at full and half doses) were compared with the phosphite-only and combined fungicide and phosphite treatments. Different letters indicate significant differences according to Tukey's test at $5 \%$ probability level.

y Fungicide 100\% dose: Revus (active ingredient [a.i.] mandipropamid) at 0.6 liters/ha at T1, T3, T7, T8, and T9; Infinito (a.i. fluopicolide + propamocarb) at 1.6 liters/ha at T4, T5, and T6; and Ranman Top (a.i. cyazofamid) at 0.5 liters/ha at T2, T10, T11, and T12. Phosphite 100\% dose: Proalexin (a.i. potassium phosphite) at 5 liters/ha.

$\mathrm{z}$ Relative area under the disease progress curve (rAUDPC).

Table 4. Phosphite contents of the harvested tubers from field experiments in 2015 and 2016, and from the field trials of Lyckeby Starch AB in 2017, presented as the means \pm standard deviation of four replicate field plot samples

\begin{tabular}{|c|c|c|c|c|}
\hline \multirow[b]{2}{*}{ Treatment $^{\mathbf{y}}$} & \multirow[b]{2}{*}{ Cultivar } & \multicolumn{3}{|c|}{ Phosphite content $\left(\mathrm{PO}_{3}\right)(\mathrm{mg} / \mathrm{kg} \mathrm{FW} \text { of tuber })^{\mathrm{z}}$} \\
\hline & & 2015 & 2016 & 2017 \\
\hline Untreated control & Kuras & 0 & $0.7 \pm 1.5$ & n.d. \\
\hline Proalexin, 5 liters/ha, $\mathrm{T} 1$ to $\mathrm{T} 12$ & Kuras & $118 \pm 10$ & $111 \pm 11$ & n.d. \\
\hline Proalexin, 2.5 liters/ha, $\mathrm{T} 1$ to $\mathrm{T} 12$ & Kuras & n.d. & $44 \pm 7$ & n.d. \\
\hline Proalexin, 1.25 liters/ha, $\mathrm{T} 1$ to $\mathrm{T} 12$ & Kuras & n.d. & $27 \pm 10$ & n.d. \\
\hline Proalexin, 5 liters/ha, T1, T3, T5, T7, T9, T11 & Kuras & n.d. & $55 \pm 3$ & n.d. \\
\hline Proalexin, 2.5 liters/ha, T1, T3, T5, T7, T9, T11 & Avenue & n.d. & n.d. & $18.2 \pm 4.4$ \\
\hline
\end{tabular}

y Active ingredient in Proalexin: potassium phosphite.

${ }^{\mathrm{z}}$ Detection limit: $1 \mathrm{mg} / \mathrm{kg}$ fresh weight $(\mathrm{FW}) ;$ n.d. = not determined. 
phosphite in the roots $3 \mathrm{~h}$ after foliar application and increased concentrations after $24 \mathrm{~h}$. In North America, phosphite products are registered and used on potato to combat late blight but, in Europe, there are no registered phosphite products for potato, partly due to concerns about the residue levels. Currently, the MRL for phosphite in potato tubers is $30 \mathrm{mg} / \mathrm{kg}$ (EU Commission Regulation No. 991/ 2014). Using phosphite alone 12 times at the recommended dose (Proalexin at 5 liters/ha, corresponding to $\mathrm{P}$ [total phosphite] at about $7,200 \mathrm{~g} / \mathrm{ha}$ ) resulted in tuber residue levels of approximately $100 \mathrm{mg} /$ $\mathrm{kg} \mathrm{FW}$. Half of the recommended phosphite dose was used in the combined treatment, and we observed a residue level of approximately $50 \mathrm{mg} / \mathrm{kg} \mathrm{FW}$. This is still above the MRL but potentially irrelevant, because starch potato tubers are not directly consumed by humans.

Table 5. Phosphite contents of the starch, pulp, and fruit juice after processing the tubers from the 2015 field experiments, presented as the means \pm standard deviation of four replicate field plot samples

\begin{tabular}{|c|c|c|c|c|c|c|}
\hline \multirow{3}{*}{$\begin{array}{l}\text { Treatment/ } \\
\text { cultivar }^{\mathbf{z}}\end{array}$} & \multicolumn{6}{|c|}{ Phosphite content $\left(\mathrm{PO}_{3}\right)(\mathrm{mg} / \mathrm{kg} \mathrm{FW})^{\mathrm{y}}$} \\
\hline & \multicolumn{2}{|c|}{ Starch } & \multicolumn{2}{|c|}{ Pulp } & \multicolumn{2}{|c|}{ Juice } \\
\hline & Kuras & Sarion & Kuras & Sarion & Kuras & Sarion \\
\hline $\begin{array}{c}\text { Untreated } \\
\text { control }\end{array}$ & 0 & 0 & 0 & 0 & 0 & 0 \\
\hline $\begin{array}{l}\text { Proalexin, } 2.5 \\
\text { liters/ha, T1, } \\
\text { T3, T5, T7, } \\
\text { T9, T11 }\end{array}$ & 0 & 0 & $19 \pm 3.6$ & $15 \pm 2.8$ & $2.7 \pm 0.58$ & $2.7 \pm 1.2$ \\
\hline $\begin{array}{l}\text { Proalexin, } 5 \\
\text { liters/ha, T1 to } \\
\text { T12 }\end{array}$ & 0 & 0 & $71 \pm 9.8$ & $63 \pm 8.6$ & $11 \pm 1.7$ & $14 \pm 1.7$ \\
\hline
\end{tabular}

Table 6. Phosphite contents of the pooled samples of fiber and protein extracted from the pulp and fruit juice, respectively, using the tubers from the 2015 field trial

\begin{tabular}{|c|c|c|c|c|}
\hline \multirow[b]{3}{*}{ Treatment/cultivar $^{\mathbf{y}}$} & \multicolumn{4}{|c|}{ Phosphite content $\left(\mathrm{PO}_{3}\right)(\mathrm{mg} / \mathrm{kg} \mathrm{DW})^{\mathrm{z}}$} \\
\hline & \multicolumn{2}{|c|}{ Fiber } & \multicolumn{2}{|c|}{ Protein } \\
\hline & Kuras & $\overline{\text { Sarion }}$ & Kuras & Sarion \\
\hline Untreated control & 0 & 0 & 0 & 0 \\
\hline $\begin{array}{l}\text { Proalexin, } 2.5 \text { liters/ha, T1, T3, } \\
\text { T5, T7, T9, T11 }\end{array}$ & 0 & 0 & 7.7 & 13 \\
\hline Proalexin, 5 liters/ha, T1 to T12 & 12.3 & 6.8 & 100 & 83.3 \\
\hline
\end{tabular}

We compiled the results of this study with the data of phosphite residues from Liljeroth et al. (2016) and found that the phosphite residues of the harvested tubers increased linearly with the amount of phosphite applied to the canopy during the cropping season (Fig. 2 ). We also included data from ware potato trials; the ware potato cultivars tended to have lower levels of phosphite residues than the starch potato cultivars. This may be related to the shorter cropping season for the earlier-maturing ware potato cultivars. Forrer et al. (2017) also reported a linear relationship between the amount of foliar-applied phosphite and the residue levels. These results suggest that the total amount of phosphite that can be applied in the field without exceeding the MRL in tubers can be predicted. For example, using phosphite at a standard rate two to three times is unlikely to exceed the MRL of $30 \mathrm{mg} \mathrm{kg}^{-1}$ of tuber. Therefore, limited use of phosphite may also apply to the table potato. Starch potato tubers, on the other hand, are not used for direct human consumption, and we could not detect phosphite residues in the starch product after processing. This suggests that higher rates of phosphite application may be possible. Phosphite was detected in other products such as the pulp and fruit juice, and the protein and fiber fractions after further processing. These fractions are used for animal feed and possibly as future food additives; therefore, the phosphite concentrations would be further diluted. According to our calculation, about $80 \%$ of the phosphite residues in the harvested tubers ended up in the process water which, in Sweden, is spread on agricultural lands.

Phosphite in the soil will ultimately be oxidized to phosphate by soil bacteria and thereby converted to fertilizer (Figueroa and Coates 2017; Thao and Yamakawa 2009). However, the kinetics of this process are unclear and need to be investigated in detail. Using phosphite as a plant protection agent must not cause the accumulation of phosphite in the soil but it is interesting to hypothesize that crop plants could use this phosphorous source as fertilizer.

The extensive use of fungicides against late blight increases the risk of fungicide resistance. Presently, there are problems with reduced sensitivity to a common late blight fungicide (fluazinam) in several countries where certain clones dominate the $P$. infestans population (Schepers et al. 2018). Using phosphite in limited doses adds another mode of action against late blight that could lower the selective pressure for fungicide resistance. A review by van den Bosch et al. (2014) concluded that the addition of a mixing partner with lowered doses of an at-risk fungicide reduces the selection of fungicide resistance. As with conventional fungicides, the overuse of phosphite may also lead to reduced phosphite sensitivity. Mulugeta et al. (2019a) observed small but significant differences in phosphite sensitivity among $P$. infestans isolates from Sweden and Ethiopia, and Huang et al. (2018) reported significant sensitivity variation among North American isolates.

In conclusion, our analyses from several trials indicate that phosphite could replace some of the fungicide treatments for late blight

Table 7. Distribution of phosphite after processing the harvested tubers from the 2015 field trial

\begin{tabular}{|c|c|c|c|c|c|}
\hline & \multicolumn{5}{|c|}{ Field application rate phosphite (Proalexin)v } \\
\hline & \multicolumn{2}{|c|}{$\begin{array}{c}\text { Analyzed phosphite concentration } \\
(\mathrm{mg} / \mathrm{kg} \mathrm{FW})^{\mathrm{w}}\end{array}$} & \multirow[b]{2}{*}{ Yield $^{x}$} & \multicolumn{2}{|c|}{$\begin{array}{c}\text { Phosphite amount (mg/kg } \\
\text { FW potato) }\end{array}$} \\
\hline & 5 liters/ha & 1.25 liters $/ \mathrm{ha}$ & & 5 liters/ha & 1.25 liters/ha \\
\hline Harvested tubers & 118 & n.d. & $\ldots$ & 118 & $30^{y}$ \\
\hline \multicolumn{6}{|l|}{ After processing } \\
\hline Starch & 0 & 0 & 0.20 & 0 & 0 \\
\hline Pulp & 71 & 19 & 0.20 & 14.2 & 3.8 \\
\hline Juice & 11 & 2.7 & 0.60 & 6.6 & 1.62 \\
\hline Total in products & $\ldots$ & $\ldots$ & $\ldots$ & 20.8 & 5.42 \\
\hline Process water ${ }^{z}$ & $\ldots$ & $\ldots$ & $\ldots$ & 97.2 & 24.6 \\
\hline Estimated percent in process water & $\ldots$ & $\ldots$ & $\ldots$ & 82.4 & 81.9 \\
\hline
\end{tabular}


without exceeding the current MRLs. We did not detect any phosphite residues in the potato starch used for human consumption. Our data also suggest that limited phosphite use does not negatively affect yield.

\section{Acknowledgments}

We thank Lyckeby Starch AB, Sweden, for support and for processing the potato samples; the Rural Economy and Agricultural Societies, Sweden, for its excellent performance in field experiments; and M. Mogren for skillful laboratory assistance.

\section{Literature Cited}

Alexandersson, E., Mulugeta, T., Lankinen, Å., Liljeroth, E., and Andreasson, E. 2016. Plant resistance inducers against pathogens in Solanaceae species-From molecular mechanisms to field application. Int. J. Mol. Sci. 17:1673.

Andreu, A. B., Guevara, M. G., Wolski, E. A., Daleo, G. R., and Caldiz, D. O. 2006. Enhancement of natural disease resistance in potatoes by chemicals. Pest Manage. Sci. 62:162-170.

Borza, T., Schofield, A., Sakthivel, G., Bergese, J., Gao, X., Rand, J., and WangPruski, G. 2014. Ion chromatography analysis of phosphite uptake and translocation by potato plants: Dose-dependent uptake and inhibition of Phytophthora infestans development. Crop Prot. 56:74-81.

Burra, D. D., Berkowitz, O., Hedley, P. E., Morris, J., Resjö, S., Levander, F., Liljeroth, E., Andreasson, E., and Alexandersson, E. 2014. Phosphite-induced changes of the transcriptome and secretome in Solanum tuberosum leading to resistance against Phytophthora infestans. BMC Plant Biol. 14:254.

Cohen, Y., and Coffey, M. D. 1986. Systemic fungicides and the control of oomycetes. Annu. Rev. Phytopathol. 24:311-338.

Cooke, L. R., and Little, G. 2002. The effect of foliar application of phosphonate formulations on the susceptibility of potato tubers to late blight. Pest Manage. Sci. 58:17-25.

Deliopoulos, T., Kettlewell, P. S., and Hare, M. C. 2010. Fungal disease suppression by inorganic salts: A review. Crop Prot. 29:1059-1075.

Edin, E., Liljeroth, E., and Andersson, B. 2019. Long term field sampling in Sweden reveals a shift in occurrence of cytochrome b genotype and amino acid substitution F129L in Alternaria solani, together with a high incidence of the G143A substitution in Alternaria alternata. Eur. J. Plant Pathol. 155:627-641.

EFSA. 2012. Conclusion on the peer review of the pesticide risk assessment of the active substance potassium phosphonates. EFSA J. 10:2963.

EFSA. 2014. Statement on the dietary risk assessment for proposed temporary maximum residue levels (t-MRLs) for fosetyl-Al in certain crops. EFSA J. 12:3695.

Figueroa, I., and Coates, J. 2017. Microbial phosphite oxidation and its potential role in the global phosphorus and carbon cycles. Adv. Appl. Microbiol. 98: 93-117.

Forrer, H.-R., Vogelgsang, S., and Musa, T. 2017. Botanicals and phosphonate show potential to replace copper for control of potato late blight. J. Fungi (Basel) 3:65.

Gao, X., Locke, S., Zhang, J., Joshi, J., and Wang-Pruski, G. 2018. Metabolomics profile of potato tubers after phosphite treatment. Am. J. Plant Sci. 9:845-864.

Haverkort, A., Boonekamp, P., Hutten, R., Jacobsen, E., Lotz, L., Kessel, G., Vossen, J., and Visser, R. 2016. Durable late blight resistance in potato through dynamic varieties obtained by cisgenesis: Scientific and societal advances in the DuRPh project. Potato Res. 59:35-66.

Huang, Z., Carter, N., Lu, H., Zhang, Z., and Wang-Pruski, G. 2018. Translocation of phosphite encourages the protection against Phytophthora infestans in potato: The efficiency and efficacy. Pestic. Biochem. Physiol. 152:122-130.

Kromann, P., Pérez, W. G., Taipe, A., Schulte-Geldermann, E., Sharma, B. P., Andrade-Piedra, J. L., and Forbes, G. A. 2012. Use of phosphonate to manage foliar potato late blight in developing countries. Plant Dis. 96: 1008-1015.

Landschoot, S., Carrette, J., Vandecasteele, M., De Baets, B., Höfte, M. Audenaert, K., and Haesaert, G. 2017. Boscalid-resistance in Alternaria alternata and Alternaria solani populations: An emerging problem in Europe. Crop Prot. 92:49-59.

Liljeroth, E., Lankinen, Å., Wiik, L., Burra, D. D., Alexandersson, E., and Andreasson, E. 2016. Potassium phosphite combined with reduced doses of fungicides provides efficient protection against potato late blight in largescale field trials. Crop Prot. 86:42-55

Lim, S., Borza, T., Peters, R. D., Coffin, R. H., Al-Mughrabi, K. I., Pinto, D. M., and Wang-Pruski, G. 2013. Proteomics analysis suggests broad functional changes in potato leaves triggered by phosphites and a complex indirect mode of action against Phytophthora infestans. J. Proteomics 93:207-223

Lobato, M. C., Machinandiarena, M. F., Tambascio, C., Dosio, G. A., Caldiz, D. O., Daleo, G. R., Andreu, A. B., and Olivieri, F. P. 2011. Effect of foliar applications of phosphite on post-harvest potato tubers. Eur. J. Plant Pathol. 130:155-163.

Lobato, M. C., Olivieri, F. P., Altamiranda, E. A. G., Wolski, E. A., Daleo, G. R., Caldiz, D. O., and Andreu, A. B. 2008. Phosphite compounds reduce disease severity in potato seed tubers and foliage. Eur. J. Plant Pathol. 122:349-358.

Machinandiarena, M. F., Lobato, M. C., Feldman, M. L., Daleo, G. R., and Andreu, A. B. 2012. Potassium phosphite primes defense responses in potato against Phytophthora infestans. J. Plant Physiol. 169:1417-1424.

Mayton, H., Myers, K., and Fry, W. 2008. Potato late blight in tubers-The role of foliar phosphonate applications in suppressing pre-harvest tuber infections. Crop Prot. 27:943-950.

Mulugeta, T., Abreha, K., Tekie, H., Mulatu, B., Yesuf, M., Andreasson, E., Liljeroth, E., and Alexandersson, E. 2019a. Phosphite protects against potato and tomato late blight in tropical climates and has varying toxicity depending on the Phytophthora infestans isolate. Crop Prot. 121:139-146.

Mulugeta, T., Mulatu, B., Tekie, H., Yesuf, M., Andreasson, E., and Alexandersson, E. 2019b. Phosphite alters the behavioral response of potato tuber moth (Phthorimaea operculella) to field-grown potato. Pest Manage. Sci. 75:616-621.

Odilbekov, F., Edin, E., Garkava-Gustavsson, L., Hovmalm, H. P., and Liljeroth, E. 2016. Genetic diversity and occurrence of the F129L substitutions among isolates of Alternaria solani in south-eastern Sweden. Hereditas 153:10.

Sandroni, M., Liljeroth, E., Mulugeta, T., and Alexandersson, E. 2020. Plant resistance inducers (PRIs): Perspectives for future disease management in the field. CAB Rev. 15:1-10.

Schepers, H., Kessel, G., Lucca, F., Förch, M., van Den Bosch, G., Topper, C., and Evenhuis, A. 2018. Reduced efficacy of fluazinam against Phytophthora infestans in the Netherlands. Eur. J. Plant Pathol. 151:947-960.

Shaner, G., and Finney, R. 1977. The effect of nitrogen fertilization on the expression of slow-mildewing resistance in Knox wheat. Phytopathology 67: 1051-1056.

Thao, H. T. B., and Yamakawa, T. 2009. Phosphite (phosphorous acid): Fungicide, fertilizer or bio-stimulator? Soil Sci. Plant Nutr. 55:228-234.

Trejo-Téllez, L. I., and Gómez-Merino, F. C. 2018. Phosphite as an inductor of adaptive responses to stress and stimulator of better plant performance. Pages 203-238 in: Biotic and Abiotic Stress Tolerance in Plants. Springer, Singapore.

van den Bosch, F., Paveley, N., van den Berg, F., Hobbelen, P., and Oliver, R. 2014. Mixtures as a fungicide resistance management tactic. Phytopathology 104:1264-1273.

Wu, L., Gao, X., Xia, F., Joshi, J., Borza, T., and Wang-Pruski, G. 2019 Biostimulant and fungicidal effects of phosphite assessed by GC-TOFMS analysis of potato leaf metabolome. Physiol. Mol. Plant Pathol. 106: $49-56$ 